\title{
P01-019 - Anti-CCP antibodies are not associated with FMF
}

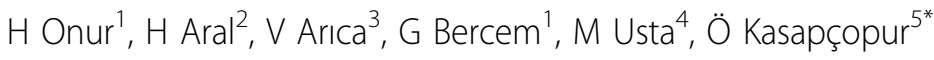 \\ From 7th Congress of International Society of Systemic Auto-Inflammatory Diseases (ISSAID) \\ Lausanne, Switerland. 22-26 May 2013
}

\begin{abstract}
Introduction
Familial Mediterranean fever (FMF) is an autosomal recessive disease that is prevalent among eastern Mediterranean populations, mainly non-Ashkenazi Jews, Armenians, Turks, and Arabs. Arthritis seen in FMF patients is generally acute monoarthritis which predominantly affecting the lower limbs, and it occurs during attack periods and also is a common clinical manifestation in patients with FMF alike Rheumatoid arthritis (RA). Anti-cyclic citrullinated peptide (anti-CCP) antibodies testing is useful in the diagnosis of Rheumatoid arthritis with high specificity. The citrulline residues are essential part of the antigenic determinants recognized by the RA antibodies.
\end{abstract}

\section{Objectives}

The aim of the study was to show the presence of anticyclic citrullinated peptide (anti-CCP) antibodies in child individuals diagnosed with Familial Mediterranean Fever (FMF).

\section{Methods}

The study group was comprised of one hundred and twenty six patients diagnosed with FMF (female/male (n):66/60); and fifthy healthy control (female/male(n):25/ 25). Clinical and laboratory assessments of the FMF patients were performed during attack-free periods. Erythrocyte sedimentation rate (ESR), serum C-reactive protein (CRP), fibrinogen and anti-CCP antibody levels were measured.

\section{Results}

Anti-CCP results were negative in healthy controls and also in all FMF patients. There was not a significant difference in anti-CCP between the patient and the control

\footnotetext{
${ }^{5}$ Pediatric Rheumatology, Istanbul University, Cerrahpasa Medical Faculty, Istanbul, Turkey

Full list of author information is available at the end of the article
}

groups. The patient individuals were divided into four groups according to genetic mutation analysis. The groups has been comprised as M694V/M694V(n=26), M694V/Other $(\mathrm{n}=38)$, Other/Other $(\mathrm{n}=46)$, Negative $(n=16)$. No significant difference detected between four mutation groups and anti-CCP levels. Our study has shown moderate positive correlations between age $\left(r_{s}=0.271 ; p=0.0020\right)$, duration of illness $\left(r_{s}=0.331\right.$; $\mathrm{p}<0.0001)$, colchicinetherapy $\left(\mathrm{r}_{\mathrm{s}}=0.259 ; \mathrm{p}=0.004\right)$ and anti-CCP levels. Also poor positive correlations between fibrinogen and anti ccp levels was detected $\left(r_{s}=0.192\right.$; $p=0.0330$ ). Anti-CCP levels has not shown significance between patients with or without arthritis $(\mathrm{p}=0.148)$.

\section{Conclusion}

In conclusion, no published data in children establish anti-CCP values in patients with FMF compared with healthy controls. Our data show that anti-CCP antibodies are not associated with FMF. Anti-CCP does not have a priority for identifying FMF arthritis from the other inflammatory arthritis.

\section{Disclosure of interest}

None declared.

\section{Authors' details}

${ }^{1}$ Department of Pediatrics, Istanbul Training and Research Hospital, Istanbul, Turkey. ${ }^{2}$ Department of Biochemistry, Istanbul Training and Research Hospital, Istanbul, Turkey. ${ }^{3}$ Department of Pediatrics, Mustafa Kemal University Medical Faculty, Hatay, Turkey. ${ }^{4}$ Department of Biochemistry, Giresun University Medical Faculty, Giresun, Turkey. ${ }^{5}$ Pediatric Rheumatology, Istanbul University, Cerrahpasa Medical Faculty, Istanbul, Turkey.

Published: 8 November 2013

doi:10.1186/1546-0096-11-S1-A23

Cite this article as: Onur et al:: P01-019 - Anti-CCP antibodies are not associated with FMF. Pediatric Rheumatology 2013 11(Suppl 1):A23.
C Biomed Central

C 2013 Onur et al; licensee BioMed Central Ltd. This is an Open Access article distributed under the terms of the Creative Commons Attribution License (http://creativecommons.org/licenses/by/2.0), which permits unrestricted use, distribution, and reproduction in any medium, provided the original work is properly cited. 